\title{
A episteme entre os meios e a comunicação
}

\section{The episteme between the media and communication}

\section{La episteme entre los medios y la comunicación}

Luís Mauro Sá Martino | Imsamartino@gmail.com

Faculdade Cásper Líbero, Escola de Comunicação. São Paulo, SP, Brasil.

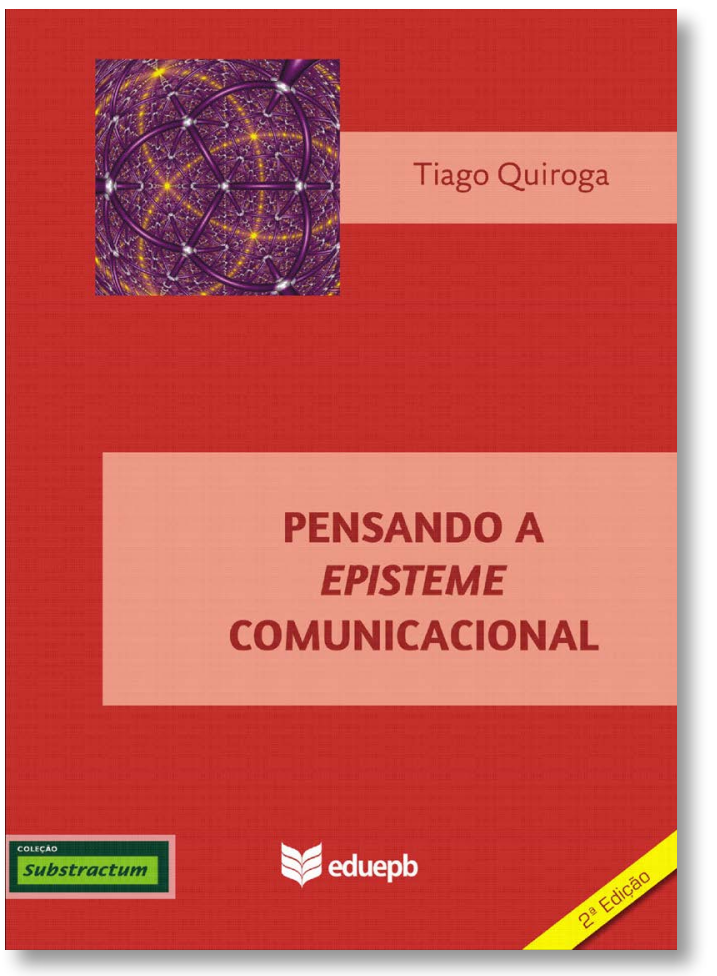

Figura 1: Capa do livro Pensando a episteme comunicacional.

Resenha do livro: Quiroga T. Pensando a episteme comunicacional. Campina Grande: Eduepb; 2013.

Palavras-chave: Comunicação; Epistemologia; Teoria da comunicação.

Keywords: Communication; Epistemology; Communication theory.

Palabras-clave: Comunicación; Epistemologia; Teoria de la Comunicación. 
Declaração de conflito de interesses: Não há conflito de interesses.

Histórico do artigo: Submetido: 13.jan.2015 | Aceito: 2.mar.2015 | Publicado: 31.mar.2016

Licença: CC BY-NC atribuição não comercial. Com essa licença é permitido acessar, baixar (download), copiar, imprimir, compartilhar, reutilizar e distribuir os artigos, desde que para uso não comercial e com a citação da fonte, conferindo os devidos créditos de autoria e menção à Reciis. Nesses casos, nenhuma permissão é necessária por parte dos autores ou dos editores.

Os debates a respeito da epistemologia da comunicação vêm se consolidando, há quase duas décadas, como um dos pontos de convergência e debate da área. Se, é verdade, as discussões teóricas quase sempre levavam em consideração questionamentos e metaquestionamentos dentro da reflexividade típica do pensamento epistemológico, por outro lado é importante observar que a emergência de uma trama de proposições especificamente dedicadas a esse tema pode ser situada em meados dos anos 1990.

O crescimento do debate epistemológico, nesse período, pode ser considerado exponencial. Não apenas em termos do número crescente de livros e artigos publicados a respeito, mas também da presença do debate no âmbito dos mais importantes eventos de comunicação e, de certo modo, pelo atravessamento do epistemológico no âmbito de várias pesquisas realizadas na área. Diante da variedade de abordagens dentro da epistemologia da comunicação, parece haver alguns poucos consensos - entre os quais, de maneira quase paradoxal, a ausência de um consenso mínimo a respeito do que seja "comunicação" e, em linhas mais detalhadas, o que constitui uma "teoria da comunicação". Longe de ser paralisante, tal paradoxo parece se desenvolver mais como uma contradição propositiva, da qual vêm emergindo significativas contribuições ao pensamento da área.

Nesse cenário, Pensando a episteme comunicacional, de Tiago Quiroga, professor da Universidade de Brasília, nasce como obra de referência no que tange ao aspecto mais proposicional encontrado na epistemologia da comunicação.

A argumentação do livro se desenvolve, entre outros aspectos, a partir do balizamento de diversos autores nacionais que vêm pensando o tema: a identificação, pelo autor, de uma genealogia, permite que ele se situe em relação às perspectivas em circulação na área. Se existem algumas opções teóricas mais salientadas, como o pensamento de Bourdieu, Vattimo e Sodré, por outro lado o diálogo não se esgota na resposta a autores, mas na proposição de uma série de distinções que auxilia a pensar a área, o fazer acadêmico e o profissional.

É interessante, nesse aspecto, verificar que o gerúndio empregado no título sugere essa abertura: ao indicar "Pensando", Quiroga parece sugerir um processo, um "trabalho em progresso", próximo de um convite ao diálogo: algo no que está se "pensando" pode ser problematizado, não fechado. Ao mesmo tempo, nota-se a opção pela palavra "episteme" e não "epistemologia": parece estar indicada aí a centralidade de um fazer teórico-científico, de uma prática de pensamento - coerente, portanto, com "pensando" - que se destaca nos estudos dos fenômenos associados à comunicação. O termo, ao mesmo tempo, remete a Foucault e, em menor medida, a Bourdieu.

Não por acaso, parte do livro é dedicada ao pensamento da formação dessa "episteme" no âmbito da comunicação, processo que não é separado, por Quiroga, das forças convergentes e divergentes que regem a formulação de qualquer episteme - e, nesse sentido, a episteme também se torna fundadora do que será entendido em seguida como o conjunto de temas e estudos de uma área. Essa episteme, síntese proposta pelo autor na confluência dos fatores políticos e epistemológicos existentes na fundação da área, 
é constituída e recortada por linhas de força que se materializam em um discurso específico a respeito não apenas do que é "comunicação", mas como, a partir desse conceito, deriva toda uma arquitetura discursiva.

E, no caso, as ambivalências do conceito respondem pela difusão epistemológica da área de comunicação o que, apesar disso, não impede a formação de uma "episteme": ao contrário, mais do que acomodações, a "episteme comunicacional” é indicada por Quiroga como um espaço de tensionamentos entre proposições que se referem ora a um, ora a outro elemento da área, em um processo irredutível a qualquer um dos polos.

Essa episteme não está desligada, evidentemente, das condições sociais em que ela se desenvolve e, sobretudo, dos problemas colocados pela realidade e que se tornam um desafio não apenas às ciências já constituídas, mas também, e talvez sobretudo, aos conhecimentos em formação.

A busca de uma episteme comunicacional parte de uma percepção, indicada pelo autor na introdução do livro, relacionada às assimetrias constitutivas da comunicação, sugerindo uma bem-vinda distinção entre "campo" e "disciplina". Se o estatuto de um "campo" da comunicação em si já é objeto de debates e discussões na obra, um dos traços mais interessantes é o tensionamento feito com a noção de "disciplina”: a relação entre a constituição política de um espaço social de pesquisa e dos saberes responsáveis por sustentá-lo em seus debates internos é altamente tensional na comunicação, na medida em que o campo e a disciplina, longe de coincidirem, às vezes parecem tecer relações tênues entre si.

Quiroga mostra como a demanda por estudos de comunicação - e os debates epistemológicos derivados disso - estão ligados a demandas de uma globalização centrada em processos comunicacionais. Ou, mais ainda, "midiáticos": o autor faz uma longa menção, no livro, ao fato de que os "estudos de comunicação", tal como entendidos de maneira ampla atualmente, têm como opção, em boa medida, eleger a "mídia" como um objeto a ser estudado a partir de categorias analíticas e operadores epistemológicos oriundos de inúmeras outras áreas, mas nem sempre da comunicação.

Em tempos nos quais as tecnologias, bem como a presença de inúmeros arcaísmos, convocam o pensamento a buscar interpelações para um diálogo, Pensando a episteme comunicacional se alinha com as principais preocupações da área, recusando-se a oferecer uma resposta monológica, mas oferecendo uma trilha para a construção de um diálogo. 